\title{
Treatment of Primary Pterygium with Conjunctival Autograft and Mitomycin C. A Comparative Study
}

\author{
Ashok K umar N arsani, Shafi M uhammad Jatoi, Siddiqa Gul and Syed Asher D abir
}

\begin{abstract}
BACKGROUND: Conjunctival autograft and Mitomycin C are two useful adjutants in the prevention of pterygium recurrence.

OBJECTIVE: To compare the recurrence rate of conjunctival autograft and Mitomycin $\mathrm{C}$ adjuvant in primary pterygium excision.

DESIGN: Quasi-experimental study on patients of primary pterygium from November 2004 to November 2006.

SETTING: Department of Ophthalmology, Liquat University of Medical and Health Sciences Jamshoro/Hyderabad.

METHOD: One hundred cases of primary pterygium were treated with conjunctival autograft and Mitomycin C $0.02 \%$ intra-operatively for 5 minutes at the bare sclera by cotton swab. Anesthesia used was topical proparacaine and local infiltration of lignocaine. Patients were followed postoperatively for 9-12 months to find the recurrence (defined as fibrovascular tissues invading the cornea $1 \mathrm{~mm}$ or more) of pterygium and complications. All surgeries were performed by one surgeon.

RESULTS: Of the hundred cases 17 were lost in follow-up. In remaining eighty-three eyes received conjunctival autograft (CAG $n=52)$ and Mitomycin $C(M M C n=31)$. There were $4(7.69 \%)$ recurrences in group A (CAG) and 8 (16.13\%) recurrences in group B (MMC). There was statistically significant difference in the recurrence rate between the two groups. The post operative complications in MMC group were two punctate epithelial keratitis, one conjunctival granuloma and one has dellen. No significant complications were encountered in conjunctival autograft group.

CONCLUSION: Simple excision of pterygium followed by conjunctival autograft has the lowest recurrence rate and minimal incidence of complications as compared to intraoperative Mitomy$\operatorname{cin} \mathrm{C}$.
\end{abstract}

KEY WORDS : Pterygium, autograft, Mitomycin C, recurrence

\section{INTRODUCTION}

Pterygium is a fibrovascular wing shaped encroachment of conjunctiva on to the cornea ${ }^{1}$. It is more frequent in areas with more ultraviolet radiation, ${ }^{2}$ especially UVR-A and UVR-B (290-400nm) is considered the most dangerous ${ }^{3,4}$. It is also more frequent in hot, dry, windy, dusty and smoky environments ${ }^{5,6}$. There is also a hereditary factor ${ }^{7}$. The complaints which it may give rise are foreign body feeling, visual loss due to corneal astigmatism or cosmetic problems ${ }^{8}$. Though anti-inflammatory drugs and lubricants have an important role in minimizing the patients discomfort but do not cure the disease. The excision of a pterygium with bare sclera was widely practiced because it was believed to be safe and simple. However, with time it becomes apparent that the recurrence rate was unacceptably high ranging from $24 \%$ to $89 \%{ }^{9}$. Several methods were implemented with the aim of improving the success rate, among them transplantation of the head of the pterygium, conjunctival flaps, lamel- lar keratoplasty, mucous membrane grafts, chemotherapy by Thiotepa, radiation therapy by radon bulbs, radium plaques, beta irradiation ablation with erbium YAG laser ${ }^{10}$ and smoothening the corneal surface with excimer laser ${ }^{11}$ has been tried. Several of them succeeded in lowering the recurrence rates but did so at the price of sight-threatening complications from the tissue damage associated with the treatment ${ }^{12}$. However, autologous conjunctival grafting seems to be the best method, giving both low recurrence rate and high safety ${ }^{13,14}$. Kenyon et al ${ }^{15}$ first described a conjunctival autograft in 1985. They documented a recurrence rate of $5.3 \%$ and infrequent minor complications. Since then, the other authors also reported that autologous conjunctival grafting seems to the best method giving both low recurrence rate and high safety ${ }^{13,16}$. The primary disadvantage of this technique is prolonged operative time required when compared to the bare sclera technique. These disadvantages are out weighed ${ }^{12}$. Unitomo, and Nori ${ }^{16}$ were the first to report the promising effect of Mitomycin C 
on the recurrence of pterygium. Mitomycin $C$ is an alkylating antineoplastic agent produced by strains of streptomyces caespinosus, which inhibits synthesis of DNA, RNA and proteins ${ }^{17}$. The current regime of Mitomycin $C$ is $0.02 \%$ to the bare sclera for 5 minutes has been found efficient in reducing the recurrence rate to a minimum ${ }^{18-20}$. In our study, we compared the recurrence rate of two different techniques.

\section{MATERIALS \& METHODS}

Hundred cases of primary pterygium were registered at the tertiary referral center, Department of Ophthalmology, Liaquat University of Medical \& Health Sciences, Jamshoro / Hyderabad. Patients were randomized in to two groups. Group A (received conjuctival autograft) and Group B (received intraoperative 0.02\% Mitomycin C). These patients had been questioned and medical data reviewed in details that none had major systemic disease such as collagen vascular disorder, diabetes mellitus. Complete ocular examination including visual acuity, intraocular pressure, extraocular movements, biomicroscopy documentation of pterygeal size and dilated fundoscopy was performed to assure that none of them had major eye disease such as dry eye, cicatrical pemphigoid, glaucoma or vitreoretinal disease. All patients were followed for 6 to 12 months to assess the recurrence rate and complications. The ocular surface was anesthetized in all patients with topical instillation of proparacaine hydrochloride $0.5 \%$ in combination with an additional sub conjunctival injection in the bed of pterygium on the bulbar side with $0.5 \mathrm{ml}$ of $2 \%$ lignocaine hydrochloride with $0.001 \%$ adrenaline. The complete excision of the head of the pterygium from the cornea was done by Bard Parker 15 number blade and the body of pterygium was dissected and excised by conjunctival scissors. In group A (CAG) area of the bare sclera was measured after pterygium excision. A free conjunctival graft was harvested from the superior conjunctiva. Dissection began from fornix to limbus.
The graft was flipped over on the cornea and tenons attachment at limbus was meticulously dissected. The flap was then excised taking care to include the limbal tissue. The graft was then moved on to the scleral bed maintaining limbus to limbus orientation. The four corners were anchored with episcleral bites using $8 / 0$ vicryl suture. In group B (MMC) intraoperative Mitomycin C $0.02 \%$ was applied to the bare sclera for 5 minutes by cotton swab. The Mitomycin $\mathrm{C}$ was prepared by adding $10 \mathrm{ml}$ of distilled water in $2 \mathrm{mg}$ ampoule of injection. The site of application was then thoroughly irrigated with at least $100 \mathrm{ml}$ of ringer lactate solution. The conjunctiva peripheral to the excised pterygium was undermined and the edges were sutured 2-3 mm from the limbus. Postoperative topical combination of corticosteroid antibiotic ointment was used and pad was applied for 24 hours. Antibiotic and corticosteroid were used 4 times a day for a month and then tapered off during the following 2-3 months. Follow-up visits were scheduled for post operative days 1,7,14, 30 and then every 2 months. The recurrence was defined as post operative fibro-vascular re-growth crossing the corneo-scleral limbus by $1.0 \mathrm{~mm}$ or more and this constituted treatment failure. All the information was filled on a profoma. Data were analyzed on SPSS version 10.0 .

\section{RESULTS}

We studied the recurrence rate of two different surgical techniques for primary pterygium excision. The demographic and the clinical details are summarized in Table I. Out of a hundred cases eighty-three eyes (52 CAG, $31 \mathrm{MMC}$ ) of 76 patients (52 CAG, $24 \mathrm{MMC}$ ) were followed. The remaining 17 patients were lost in follow up. The recurrence in-group A was 7.69\% whereas recurrence in group B was $16.13 \%$. In-group A recurrences were, one within 2 months, two within 5-6 months and one within 9-10 months (Table II). In group B recurrences were two within 3-4 months, two within 5-6 months and one within 9-10 months. The

TABLE I:

DEMOGRAPHIC AND CLINICAL DATA OF PATIENTS IN GROUP 1 AND GROUP 2

\begin{tabular}{|c|c|c|c|c|c|c|c|c|}
\hline \multirow{2}{*}{$\begin{array}{l}\text { Groups } \\
\text { With No } \\
\text { of eyes }\end{array}$} & \multirow{2}{*}{$\begin{array}{c}\text { Age range } \\
\text { (Years) }\end{array}$} & \multirow{2}{*}{$\begin{array}{c}\text { Mean Age } \\
\text { (Years) }\end{array}$} & \multicolumn{2}{|c|}{ Sex } & \multicolumn{2}{|c|}{ Laterally } & \multicolumn{2}{|c|}{ Population Type } \\
\hline & & & Male & Female & Right & Left & Rural & Urban \\
\hline CAG 52 & $29-70$ & 44.04 & $\begin{array}{c}31 \\
(59.62 \%)\end{array}$ & $\begin{array}{c}21 \\
(40.38 \%)\end{array}$ & $\begin{array}{c}36 \\
(69.23 \%)\end{array}$ & $\begin{array}{c}16 \\
(30.76 \%)\end{array}$ & $\begin{array}{c}37 \\
(71.15 \%)\end{array}$ & $\begin{array}{c}15 \\
(28.84 \%)\end{array}$ \\
\hline MMC 31 & $34-62$ & 44.84 & $\begin{array}{c}20 \\
(64.52 \%)\end{array}$ & $\begin{array}{c}11 \\
(35.48 \%)\end{array}$ & $\begin{array}{c}17 \\
(54.83 \%)\end{array}$ & $\begin{array}{c}14 \\
(45.16 \%)\end{array}$ & $\begin{array}{c}23 \\
(74.19 \%)\end{array}$ & $\begin{array}{c}8 \\
(25.81 \%)\end{array}$ \\
\hline $\begin{array}{l}\text { CAG + } \\
\text { MMC } 83\end{array}$ & $29-70$ & 44.44 & $\begin{array}{c}51 \\
(61.44 \%)\end{array}$ & $\begin{array}{c}32 \\
(38.55 \%)\end{array}$ & $\begin{array}{c}53 \\
(63.86 \%)\end{array}$ & $\begin{array}{c}30 \\
(36.14 \%)\end{array}$ & $\begin{array}{c}60 \\
(72.29 \%)\end{array}$ & $\begin{array}{c}23 \\
(27.71 \%)\end{array}$ \\
\hline
\end{tabular}

CAG = Conjunctival Autograft, MMC = Mitomycin C 
TABLE II:

NUMBER OF RECURRENCES OF CAG VS MMC

\begin{tabular}{|l|c|c|c|}
\hline $\begin{array}{c}\text { Duration } \\
\text { (in months) }\end{array}$ & $\begin{array}{c}\text { CAG } \\
(\mathbf{n}=\mathbf{5 2})\end{array}$ & $\begin{array}{c}\text { MMC } \\
(\mathbf{n}=\mathbf{3 1})\end{array}$ & $\begin{array}{c}\text { CAG+MMC } \\
(\mathbf{n}=\mathbf{8 3})\end{array}$ \\
\hline $0-2$ & 1 & 0 & 1 \\
\hline $3-4$ & 0 & 2 & 2 \\
\hline $5-6$ & 2 & 2 & 4 \\
\hline $7-8$ & 1 & 0 & 1 \\
\hline $9-10$ & 0 & 1 & 1 \\
\hline $11-12$ & 0 & 0 & 0 \\
\hline Total & $\mathbf{4 ( 7 . 6 9 \% )}$ & $\mathbf{5 ( 1 6 . 1 3 \% )}$ & $\mathbf{9 ( 1 0 . 8 4 \% )}$ \\
\hline
\end{tabular}

difference in recurrence rate was statistically significant. No significant complications were noted in group A except varying level of discomfort, foreign body sensation tearing and redness for some period in few patients. There were two patients with punctate epithelial keratits, one granuloma and one dellen in group B. No scleral thinning, necrosis, perforation or any other visually significant complication was encountered in either group.

\section{DISCUSSION}

Various surgical techniques have been employed to treat the pterygium. The unpredictable rates and timing of recurrence ${ }^{21}$ are the main problem encountered after various treatment modalities. A recurrent pterygium can be associated with decreased visual acuity due to involvement of visual axis and/or irregular astigmatism, extraocular motility restriction and symblepharon formation ${ }^{22}$. Because of high recurrence rate the bare sclera excision alone proved unsatisfactory. Adjunctive treatment after bare sclera excision with Beta irradiation reduced recurrence rate to as low as $0.5 \%-10 \%{ }^{23}$, but was associated with significant complications such as scleral necrosis. In 1985, Kenayn et al ${ }^{15}$ published report describing conjunctival autografting as a promising technique in the treatment of pterygium. They documented the recurrence rate of $5.3 \%$ in the primary pterygium group. Since then a number of papers on the success of conjunctival grafting have been published with various success rates. Compared with the bare sclera method, conjunctival autograft is more technically demanding procedure; surgeon factors such as experience, techniques, etc. may have a profound influence on the recurrence rate ${ }^{15}$. More over conjunctival grafts including limbal epithelium generally yield better results because it will help to restore its barrier function ${ }^{24}$. In 1998, Lewallen $\mathrm{S}^{25}$ published report of a randomized trial of the conjunctival autografting technique for pterygium removal. She documented a lower recurrence rate $(21 \%)$ in grafted cases compared with bare sclera technique (37\%). Riodan-Eva et al ${ }^{26}$ of Moorfields Eye Hospital
London supported Lewallen S finding when they reported a statistically significant reduction in recurrence rate following conjunctival autografting for pterygium. They quoted a probability of recurrences of $14 \%$ with this procedure at 36 months after surgery. In 2005 Fahmi et al ${ }^{27}$ reported $13.33 \%$ recurrence rate with conjunctival autograft. In our study recurrence rate was found to be $7.69 \%$. An alternate to conjunctival autograft technique to improve outcome is use of Mitomycin $\mathrm{C}$. In our study the recurrence rate with $\mathrm{MMC}$ is $16.13 \%$ as compared with Chen et al ${ }^{13}$ reported $38 \%$ recurrence rate with application of $0.4 \mathrm{mg} / \mathrm{ml}$ for 3 minutes. While Manning et al ${ }^{19}$ reported $10.5 \%$. Sharma et al ${ }^{28}$ compared MMC with conjunctival graft and $\mathrm{Ma}$ et al ${ }^{29}$ postoperative MMC, but neither showed any statistical difference. However these studies failed to show any difference between MMC and conjunctival autograft. The results of our study reported an advantage of conjunctival autograft over Mitomycin C. Our results are compatible with national and international studies.

\section{CONCLUSION}

Simple excision of pterygium followed by conjunctival autograft has the lowest recurrence rate and minimal incidence of complications as compared to intraoperative Mitomycin C.

\section{REFERENCES}

1. Wong AK, Rao SK, Leug At, Poon AS, Lam DS. Inferior Limbal - Conjunctival autograft transplantation for recurrent pterygium. Indian J Ophthalmol 2000; 48; 21-4.

2. Moran DJ, Hollows FC. Pterygium and ultraviolet radiation: a positive correlation. $\mathrm{Br} \mathrm{J}$ Ophthalmol 1984; 68:343-6.

3. Taylor HR, West SK, Rosenthal FS, Munoz B, Newland HS, Emmet AE. Corneal changes associated with chronic UV irradiation. Arch Ophthalmol 1989; 107(10): 1481-4.

4. Detorakis ET, Zafiropoulos A, Arvanitis DA, Spandidos DA. Detection of point mutations at codon of $\mathrm{KI}$-ras in ophthalmic pterygia. Eye 2005; 19: 210-4.

5. Nakaishi H, Yamamoto M, I Shida M. Pingueculae and pterygia in motorcycle policeman. Ind Health 1997; 35:325-9.

6. Norn M, Franck C .Long-term changes in the outer part of the eye in welders. Prevelence of spheroid degeneration, pinguecula, pterygium, and corneal cicatrices. Acta Ophthalmol (Copenh) 1990; 69:382-6.

7. Booth F. Heredity in one hundred patients admitted for excision of pterygia. Aust $\mathrm{N} Z \mathrm{~J}$ Ophthalmol 1985 ; 13:59-61.

8. Keizer R.J. Pterygium excision with or without 
postoperative irradiation, a double-blind study. Documenta Ophthalmologica 1982; 52: 309-15

9. Jaros PA, DeLuise VP. Pingueculae and pterygia. Surv Ophthalmol 1988; 33:41-9.

10. Koranyi G, Seregard S, Kopp ED. Cut and paste: a no suture, small incision approach to pterygium surgery. Br J Ophthalmol 2004;88: 911-4.

11. Seiler T, Schnelle B, Wollensak J. Pterygium excision using 193-nm excimer laser smoothing and topical Mitomycin C. Ger J Ophthalmol 1992;1:429-31.

12. Varssano D, Michaeli-Cohen A, Loewenstein A. Excision of pterygium and conjunctival autograft. Isr Med Assoc J 2002; 4:1097-100.

13. Chen PP, Ariyasu RG, Kaza V, LaBree LD, McDonnell PJ. A randomized trial comparing Mitomycin $\mathrm{C}$ and conjunctival autograft after excision of primary pterygium. Am J Ophthalmol 1995;120:151-60.

14. Prabhasawat P , Barton K, Burkett G. Comparison of conjunctival autografts, amniotic membrane grafts, and primary closure for pterygium excision. Ophthalmology 1997;104: 974-85.

15. Kenyon KR, Wagoner MD, Hettinger ME. Conjunctival autograft transplantation for advanced and recurrent pterygium. Ophthalmology 1985;92:1461-70.

16. Unitomo N, Nori S. Studies on pterygium. Part IV. A treatment of pterygium by Mitomycin $C$ instillation. Nippon Ganka Gakkai Zasshi 1963; 67:601-7.

17. Saifuddin S, Zawawi AE. Scleral changes due to Mitomycin C after Pterygium excision: A report of two cases. Ind J Ophthalmol 1995; 43:75-76.

18. Lam DS, Wong AK, Fan DS, Chew S, Kwok PS, Tso MO. Intraoperative Mitomycin $C$ to prevent recurrence of pterygium after excision: a 30-month follow-up study. Ophthalmology 1998; 105:901-4.

19. Manning CA, Kloess PM, Diaz MD, Yee RW. Intraoperative Mitomycin in primary pterygium excision. A prospective, randomized trial. Ophthalmology
$1997 ; 104: 844-8$

20. Avisar R, Arnon A, Avisar E, Weinberger D. Primary pterygium recurrence time. Isr Med Assoc $\mathrm{J}$. 2001;3(11):836-7.

21. Frau E, Labetoulle M, Lautier-Frau M, Hutchinson $\mathrm{S}$, Offret $\mathrm{H}$. Corneo -conjunctival autograft transplantation for pterygium surgery. Acta Ophthalmol Scand. 2004; 82(1):59-63.

22. Shimazaki J, Shinozaki N, Tsubota K. Transplantation of amniotic membrane and limbal autograft for patients with recurrent pterygium associated with symblepharon. Br. J Ophthalmol 1998; 82:235-40.

23. MacKenzie FD, Hirst LW, Kynaston B, Bain C. Recurrence rate and complications after beta irradiation for pterygia. Ophthalmology 1991; 98:1776-81.

24. Young AL, Leung GY, Wong AK, Cheng LL, Lam DS. A randomised trial comparing 0.02\% Mitomycin $\mathrm{C}$ and limbal conjunctival autograft after excision of primary pterygium.Br J Ophthalmol 2004; 88(8):995-7.

25. Lewallen S. A randomised trial of conjunctival autografting for pterygium in the tropics. Ophthalmology 1989; 96:1612-4.

26. Riordan-Eva P, Kielhorn I, Ficker LA, Steele AD, Kirkness CM. Conjunctival autografting in the surgical management of pterygium. Eye 1993; 7:6348.

27. Fahmi M S, Sayed J, Ali M. After removal of pterygium role of Mitomycin and conjunctival autograft. Ann Abbasi Shaheed Hosp KMD Coll 2005; 10:757-61.

28. Sharma A, Gupta A, Ram J. Low-dose intraoperative Mitomycin- $C$ versus conjunctival autograft in primary pterygium surgery: long term follow-up. Ophthalmic Surg Lasers 2000; 31:301-7.

29. Ma DH, See LC, Liau SB, Tsai RJ. Amniotic membrane graft for primary pterygium: comparison with conjunctival autograft and topical Mitomycin C treatment. Br J Ophthalmol 2000; 84:973-8.

\section{AUTHOR AFFILIATION:}

\section{Dr. Ashok Kumar Narsani (Corresponding Author)}

Department of Ophthalmology

Liaquat University Eye Hospital Hyderabad, Sindh-Pakistan.

Email: amnarsani@hotmail.com

\section{Prof. Shafi Muhammad Jatoi}

Department of Ophthalmology

Liaquat University Eye Hospital Hyderabad, Sindh-Pakistan.

\section{Dr. Siddiqa Gul}

Department of Ophthalmology

Liaquat University Eye Hospital Hyderabad, Sindh-Pakistan.

Dr. Syed Asher Dabir

Department of Ophthalmology

Liaquat University Eye Hospital Hyderabad, Sindh-Pakistan. 